\title{
Thanatophoric Dysplasia
}

\author{
Gurubacharya SM${ }^{1}$, Subedi $K^{2}$, Aryal DR ${ }^{3}$ \\ ${ }^{1}$ Dr. Simmi Misra Gurubacharya. MBBS.MD. Registrar, ${ }^{2}$ Dr. Kalpana Subedi. MBBS.MD. ${ }^{3}$ Dr. Dhan Raj Aryal \\ Consultant Paediatrician and Neonatologist. NICU, Maternity Hospital (Prasuti Griha), Kathmandu, Nepal.
}

Address for Correspondence: Dr. Simmi Misra Gurubacharya, E-mail : sm_pul@rediffmail.com

A full-term baby was born to non-consanguinous parents having micromelic upper and lower limbs, brachydatyly, large head, frontal bossing, narrow thorax, protuberant abdomen and deep skin creases with respiratory distress (Figure 1). Radiological examination revealed narrow thoracic cage with short ribs, shortened long bones with flaring of metaphysis, curved femora, short pelvis with medial acetabular spurs and flattened 'H'shaped vertebrae (Figure 2,3). The diagnosis of Thanatophoric dysplasia (TD) Type I was made.

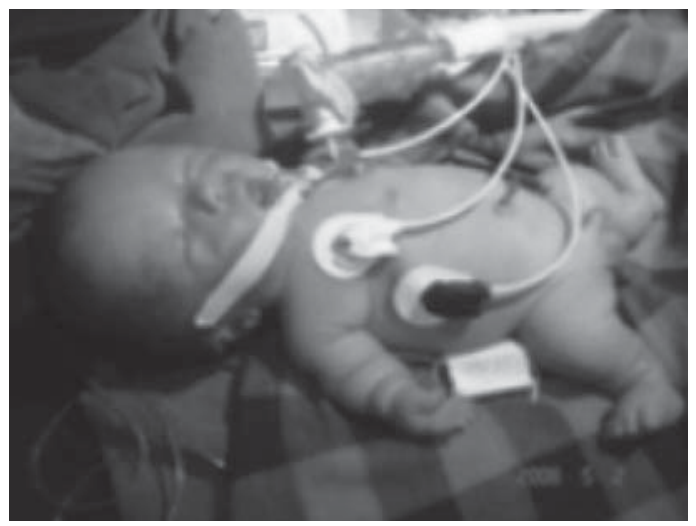

Fig.1: Showing Classic Features.

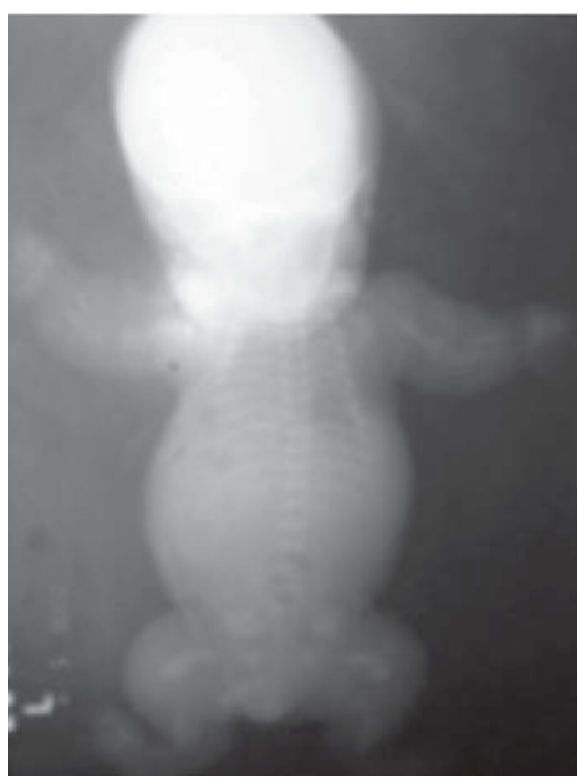

Fig. 2: Showing Radiological Features.

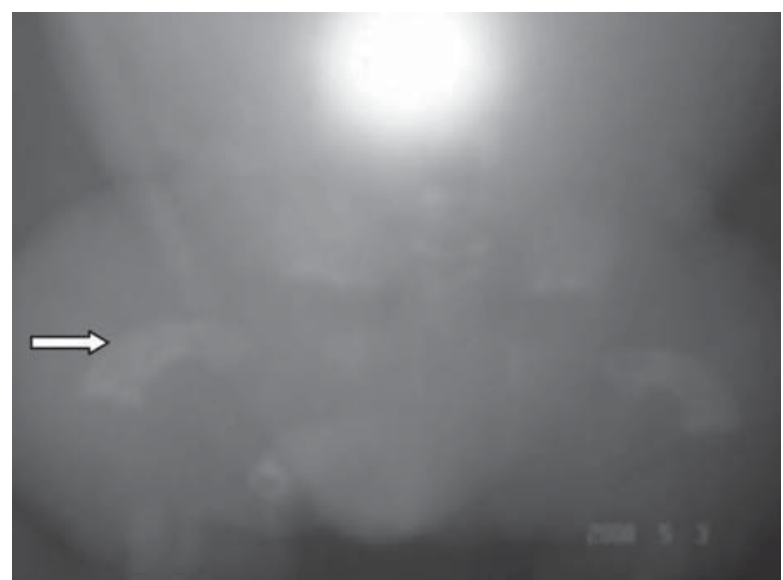

Fig. 3: Showing Curved Femur (Telephone Receiver).

TD is a severe skeletal dysplasia that is lethal in the newborn period. It is characterized by extremely short limbs, a narrow thorax, macrocephaly and normal trunk length. Two major forms are described. Type I is charaterized by a normal shaped skull, curved long bones(shaped like a telephone receiver); the femurs are most affected and very flat vertebral bodies(platyspondyly). Type II is characterized by clover leaf-shaped skull, straight femora and flatter vertebral bodies ${ }^{1,2}$. Other abnormalities found are temporal lobe dysplasia, hydrocephalus, severe growth deficiency, large fontanel, small foramen magnum and short base of skull, small-sausage like fingers, lack of ossification in secondary centers at knee, small and squarish scapulae, short and squarish pelvis with small sciatic notch ${ }^{3}$. They are usually stillborn or die shortly after birth from respiratory failure either due to narrow thorax with pulmonary hypoplasia or due to compression of the brainstem. It occurs in 1 in 20,000 to 50,000 births $^{4}$. Autosomal dominant mutations in the fibroblast growth factor receptor 3 gene (FGFR3), which has been mapped to chromosome band $4 \mathrm{p} 16.3$ results in both subtypes. Polyhydramnios is frequently found. Prenatal diagnosis can be established by ultrasonography in the second trimester ${ }^{5}$. Differential diagnosis includes achondrogenesis, homozygous achondroplasia, hypophosphatasia and osteogenesis imperfecta. Intubation may be performed as aggressive treatment for respiratory distress but the long term prognosis is poor. 


\section{References:}

1. Spranger J. Radiologic Nosology of Bone Dysplasias. Am J Med Genet 1989; 34: 96-104.

2. Macken MB, Grantmyre EB, Rimoin DL, Lachman RS. Normal Sonographic Appearance of a Thanatophoric Dwarf Variant Fetus at 13 weeks of Gestation. Am J Roentgen 1991; 156: 149-150.

3. Jones LK. Thanatophoric Dysplasia. In: Smith's Recognisable Patterns of Human Malformation, 5th edn. W.B.Saunder's Company, 1997; pp338339.
4. Accessed from; Genetics Home Reference;ghr. nlm.nih.gov/condition=thanatop.d.

5. Sahinoglu Z, Uludogan M, Gurbuz A, Karateke A. Prenatal Diagnosis of Thanatophoric Dysplasia in the Second Trimester: Ultrasonography and other Diagnostic Modalities. Arch Gynecol Obstet 2003 Nov; 269(1):57-61. 